Original

\title{
Presumed Idiosyncratic Adverse Cutaneous Drug Reactions in 29 Cats (1997-2012)
}

\author{
特発性皮膚薬物有害反応が疑われた猫の 29 例 \\ Lisa Benson, Danny W. Scott*, William H. Miller, Jr. \\ Department of Clinical Sciences, College of Veterinary Medicine, Cornell University \\ Received January 29, 2015 and accepted May 3, 2015
}

\begin{abstract}
We performed a retrospective evaluation of 29 cats with presumed idiosyncratic adverse cutaneous drug reactions (ACDR). ACDR accounted for $2 \%$ of the cats examined by the Dermatology Service over a period of 15 years. No breed, age, sex, or retroviral predilections were found. The most common cutaneous reaction patterns were contact dermatitis, contact otitis externa, allergy-like pruritus, and vasculitis. The most commonly incriminated drugs were amoxicillin clavulanate and chlorhexidine scrub. Drug withdrawal resulted in resolution of the skin eruptions within 2 to 6 weeks in 25 cats, and 12 weeks in 4 cats. Two cats with cefovecin-associated necrotizing vasculitis required additional anti-inflammatory therapy.

Key words: adverse cutaneous drug reaction, cat

要 約：特発性皮膚薬物有害反応 (ACDR) が疑われた 29 例の猫に関する後ろ向き研究が行われ た。ACDR は過去 15 年間に皮膚科診療施設を受診した猫の $2 \%$ をめた。好発品種, 性差あるい はレトロウイルス感染との特別な関連は認められなかった。皮膚の反応パターンのうち最も多かっ たものは接触皮膚炎，接触性外耳炎，アレルギーに類似したかゆみ，㧍よび血管炎であった。原因 薬物として最も多かったものはクラブラン酸アモキシシリンおよびクロルヘキシジン含有洗浄液で あった。2 5 例の猫では薬物の中止により $2 \sim 6$ 週後に, 4 例では 12 週後に症状の改善が認められた。 2 例の猫ではセフォベシン投与に関連した壊死性血管炎が認められ，治療には抗炎症療法が必要で あった。 キーワード：皮膚薬物有害反応，猫
\end{abstract}

(Jpn J Vet Dermatol 2015, 21 (3): 143-148)

\section{Introduction}

Adverse cutaneous drug reactions (ACDR) are divided into two categories: dose-dependent or idiosyncratic ${ }^{6,14)}$. With dose-dependent ACDR, the onset and severity of the clinical signs correlate with the dose received by the patient ${ }^{6,14)}$. The clinical signs are known adverse effects of the drug in question or are related to the physical or chemical properties of the parent drug

* Correspondence to: Danny W. Scott, (Department of Clinical Sciences, College of Veterinary Medicine, Cornell University), Ithaca, New York 14853-6401, USA

FAX+1-607-253-3534E-mail: shb3@cornell.edu or one of its metabolites. Dose-dependent ACDR are relatively common, predictable, and could happen to any patient.

Idiosyncratic ACDR occur independently of dose, and are not directly related to the pharmacologic, physical, or chemical properties of the $\operatorname{drug}^{6,14)}$. They are relatively uncommon and unpredictable. The pathomechanisms of idiosyncratic ACDR are not well understood, but an allergic (hypersensitivity) basis is often postulated ${ }^{6,14)}$. The various theories of drug allergy pathogenesis include the classic hypersensitivity reactions (Types I, II, III, and IV) of Gell and Coombs, the prohapten hypothesis, the danger theory, and the pharmacological 
Table 1. Diagnostic criteria for adverse cutaneous drug reaction ${ }^{6}$

1. A drug not received previously is given for more than 7 days prior to the onset of the eruption, but repeat drug exposure can result in a more rapid onset of the eruption.

2. The eruption is occurring while the patient is receiving the drug, or the drug has only recently been discontinued.

3. Stopping the drug results in resolution of the eruption, generally within 7 to 14 days.

4. If repeat exposure occurs, a similar eruption occurs.

5. Other causes for the eruption are ruled out.

6. Features of the eruption are consistent with a drug eruption and correlate with eruptions the suspect drug is known to cause.

interaction concept. These theories are discussed in detail elsewhere ${ }^{6,14)}$.

In 1998 we summarized data on 34 cats with presumed idiosyncratic ACDR reported from 1968 through $1996^{11)}$. Since then another 5 cats with presumed idiosyncratic ACDR have been reported: erythema multiforme (ampicillin) ${ }^{9}$, pemphigus foliaceus (amoxicillin) $)^{9)}$, self-induced hair loss (valproic acid) ${ }^{15}$, pruritic ulcerative dermatitis of the head (amoxicillin clavulanate $)^{12)}$, and sterile pustular dermatitis (cephalexin) $)^{4)}$. In addition, facial edema or generalized pruritus accounted for $5.7 \%$ and $1.9 \%$, respectively, of vaccine-associated adverse events in cats ${ }^{7}$.

The purpose of this article is to report the findings of a retrospective study of an additional 29 cats with presumed idiosyncratic ACDR.

\section{Materials and Methods}

A retrospective study was conducted on presumed idiosyncratic ACDR in 29 cats examined by the Dermatology Service of the Cornell University Hospital for Animals (CUHA) over a 15-year period (1997 to 2012). Medical records were reviewed for the following information:

1. Signalment (breed, age, sex).

2. Cutaneous reaction pattern.

3. Feline leukemia virus (FeLV) and feline immunodeficiency virus (FIV) status.

4. Suspect drug.

5. Time period suspect drug had been administered prior to the onset of ACDR.

6. Time period to resolution of ACDR following cessation of suspect drug.

7. Duration of follow-up after ACDR had resolved.

Diagnosis was based on standard criteria (Table

$1)^{6}$. Skin scrapings, trichography, and cytology were performed, as indicated, to rule-out concurrent parasitic, fungal, or bacterial involvement. Rechallenge with the suspect drug was not performed. Skin biopsies were performed in 4 cats (cases 23, 24, 28, 29). Breed and sex data for the cats with ACDR were compared to those for the general CUHA cat population for the same time period using the relative risk (RR) calculation:

$$
\mathrm{RR}=\frac{\text { data for ACDR cats }}{\text { data for CUHA cats }}
$$

An RR of 2.0 or greater was considered significant.

\section{Results}

ACDR was diagnosed in $2 \%$ ( 29 of 1,350 cats) of the feline dermatology cases and $0.1 \%$ (29/22,000 cats) of all cats examined at the CUHA over a 15 -year period (Table 2). Domestic shorthair cats accounted for $70 \%$ (20/29) of the cats with ACDR, and $80 \%$ of the CUHA cat population $(\mathrm{RR}=0.9)$. ACDR was also diagnosed in domestic longhair (4 cases), Siamese (2 cases), Himalayan ( 2 cases), and Burmese ( 1 case) cats.

Males and females accounted for $66 \%$ and $34 \%$, respectively, of the cats with ACDR, and for $50 \%$ $(\mathrm{RR}=0.7)$ and $50 \%(\mathrm{RR}=1.3)$, respectively, of the CUHA cat population. The sex was not recorded for $2 \%$ of the CUHA cat population. The cats ranged from 0.5 to 16 years of age. No cat was FIV-positive, and only one cat (case 21) was FeLV-positive.

The most commonly incriminated drugs were amoxicillin clavulanate (cases $3,5,11,23$ ) and chlorhexidine scrub (cases 1, 9, 26, 27). Contact reactions accounted for $45 \%$ (13/29 cats) of the presumed ACDR: contact dermatitis associated with antiseptic scrub and parasiticidal spot-on products (cases 1, 2, 4, 8, 9, 16, 26, 27) and contact otitis externa associated with otic drop preparations (cases 17-19, 22, 25). Of the presumed ACDR associated with systemic medications, the most common reaction patterns were allergy-like pruritus of the face, pinnae, and paws (cases 
Table 2. Data on presumed adverse cutaneous drug reactions in 29 cats

\begin{tabular}{|c|c|c|c|c|c|c|}
\hline Case & Breed $^{\dagger}$ & $\operatorname{Sex}^{\circ}$ & $\begin{array}{c}\text { Age } \\
\text { (years) }\end{array}$ & Presumed offending drug & Cutaneous reaction pattern & $\begin{array}{c}\text { Follow-up } \\
\text { period } \\
\text { (months) }\end{array}$ \\
\hline 1 & Siamese & $\mathrm{MC}$ & 0.5 & $2 \%$ chlorhexidine scrub $^{\mathrm{a}}$ & Contact dermatitis & 1 \\
\hline 2 & DSH & $\mathrm{MC}$ & 6.0 & Selamectin spot-on ${ }^{\mathrm{b}}$ & Contact dermatitis & 1 \\
\hline 3 & DLH & $\mathrm{MC}$ & 6.0 & Amoxicillin clavulanate $\mathrm{PO}^{*}$ & Vasculitis & 1 \\
\hline 4 & DLH & FS & 4.0 & Imidacloprid spot-on $^{\mathrm{c}}$ & Contact dermatitis & 1 \\
\hline 5 & DSH & FS & 7.0 & Amoxicillin clavulanate PO & Mucocutaneous erosions and crusts & 1 \\
\hline 6 & DSH & FS & 2.0 & Timentin $\mathrm{SQ}^{\ddagger}$ & Facial pruritus & 3 \\
\hline 7 & DSH & $\mathrm{MC}$ & 16.0 & Trimethoprim sulfadiazine PO & Pinnal pruritus & 2 \\
\hline 8 & DSH & FS & 6.0 & Fipronil spot-on $^{\mathrm{d}}$ & Contact dermatitis & 3 \\
\hline 9 & DSH & $\mathrm{MC}$ & 4.0 & $2 \%$ chlorhexidine scrub $^{\mathrm{a}}$ & Contact dermatitis & 1 \\
\hline 10 & DSH & $\mathrm{MC}$ & 13.0 & Marbofloxacin PO & Facial pruritus & 1.5 \\
\hline 11 & DSH & $\mathrm{MC}$ & 1.0 & Amoxicillin clavulanate PO & Pinnal pruritus & 36 \\
\hline 12 & Burmese & FS & 12.0 & Enrofloxacin SQ & Injection site necrosis and slough & 4 \\
\hline 13 & DSH & $\mathrm{MC}$ & 4.0 & Cefadroxil PO & Acrocyanosis & 4 \\
\hline 14 & DSH & $\mathrm{MC}$ & 9.0 & Spirinolactone PO & Facial pruritus & 12 \\
\hline 15 & DSH & $\mathrm{F}$ & Adult & Imidacloprid spot-on $^{\mathrm{c}}$ & Contact dermatitis & 12 \\
\hline 16 & DSH & $\mathrm{MC}$ & 8.0 & Imidacloprid spot-on $^{\mathrm{c}}$ & Contact dermatitis & 24 \\
\hline 17 & Himalayan & FS & 1.5 & Miconazole and gentamicin otic drops ${ }^{\mathrm{e}}$ & Contact otitis externa & 36 \\
\hline 18 & DSH & $\mathrm{MC}$ & 3.0 & Pyrethrin otic drops ${ }^{\mathrm{f}}$ & Contact otitis externa & 2 \\
\hline 19 & DSH & $\mathrm{MC}$ & 1.0 & $\begin{array}{l}\text { Neomycin, thiabendazole, } \\
\text { and dexamethasone otic drops }{ }^{\mathrm{g}}\end{array}$ & Contact otitis externa & 2 \\
\hline 20 & Himalayan & $\mathrm{MC}$ & 2.0 & Sulfladimethoxine and ormetoprim PO & Facial, pinnal and pedal pruritus & 2 \\
\hline 21 & DSH & FS & 1.5 & Clindamycin PO & Vasculitis & 5 \\
\hline 22 & DLH & $\mathrm{MC}$ & 1.5 & Gentamicin and betamethasone otic drops ${ }^{\mathrm{h}}$ & Contact otitis externa & 48 \\
\hline 23 & DSH & $\mathrm{MC}$ & 1.0 & Amoxicillin clavulanate PO & Sterile neutrophilic pustulosis & 36 \\
\hline 24 & DLH & $\mathrm{MC}$ & 1.5 & Enrofloxacin PO & Erythema multiforme & 24 \\
\hline 25 & DSH & FS & 5.0 & Miconazole otic drops ${ }^{\mathrm{i}}$ & Contact otitis externa & 12 \\
\hline 26 & DSH & $\mathrm{MC}$ & 2.0 & $2 \%$ chlorhexidine scrub ${ }^{a}$ & Contact dermatitis & 12 \\
\hline 27 & DSH & FS & 5.0 & $2 \%$ chlorhexidine scrub ${ }^{a}$ & Contact dermatitis & 12 \\
\hline 28 & DSH & $\mathrm{MC}$ & 1.0 & Cefovecin SQ & Vasculitis & 8 \\
\hline 29 & Siamese & $\mathrm{MC}$ & 3.0 & Cefovecin SQ & Vasculitis & 24 \\
\hline
\end{tabular}

${ }^{\dagger} \mathrm{DSH}=$ domestic shorthair; $\mathrm{DLH}=$ domestic longhair. ${ }^{\circ} \mathrm{MC}=$ castrated male; $\mathrm{FS}=$ spayed female; $\mathrm{F}=$ intact female. $* \mathrm{PO}=$ orally. ${ }^{*} \mathrm{SQ}=$ subcutaneously. ${ }^{\mathrm{a}}$ Chlorhexidine $\mathrm{Scrub}^{\circledR}$ (chlorhexidine gluconate, citric acid, cocamide DEA, hydroxyethylcellulose, isopropyl alcohol, lauramine oxide). ${ }^{b}$ Revolution ${ }^{\circledR}$ (selamectin, isopropyl alcohol, butylated hydroxytoluene). ${ }^{\mathrm{C}}$ Advantage ${ }^{\circledR}$ (imidacloprid). ${ }^{\mathrm{d}}$ Frontline ${ }^{\circledR}$ (fipronil). ${ }^{\mathrm{e}}$ Miconazole and gentamicin (compounded by local veterinarian). ${ }^{\mathrm{f}}$ Pyrethrin drops (pyrethrins). ${ }^{\mathrm{g}}$ Tresaderm ${ }^{\circledR}$ (thiabendazole, neomycin, dexamethasone, glycerin, propylene glycol, purified water, hypophosphorous acid, calcium hypophosphite, ethyl alcohol, benzoyl alcohol). ${ }^{\mathrm{h}}$ Gentaotic ${ }^{\circledR}$ (gentamicin, betamethasone, hydroxycellulose, glacial acetic acid, purified water, ethanol, benzoyl alcohol, glycerin, propylene glycol). ${ }^{\mathrm{i}}$ Miconazole Nitrate Topical ${ }^{\circledR}$ (miconazole, polyethylene glycol 400, ethyl alcohol).

$6,10,11,14,20)$ and vasculitis (cases 3, 21, 28, 29). One cat (case 23) had a sterile neutrophilic pustulosis affecting the pinnae and pawpads. The eruption resembled pemphigus foliaceus, but acantholytic keratinocytes were not found cytologically or histopathologically.
Fifteen of 29 cats $(52 \%)$ had prior exposure to the offending drug (cases 2-8, 11, 15-20, 25). One cat (case 29) with a presumed ACDR to cefovecin had been previously treated with another cephalosporin (cefadroxil). All cats had received the offending drugs for at least 7 days prior to the recognition of the ACDR. 


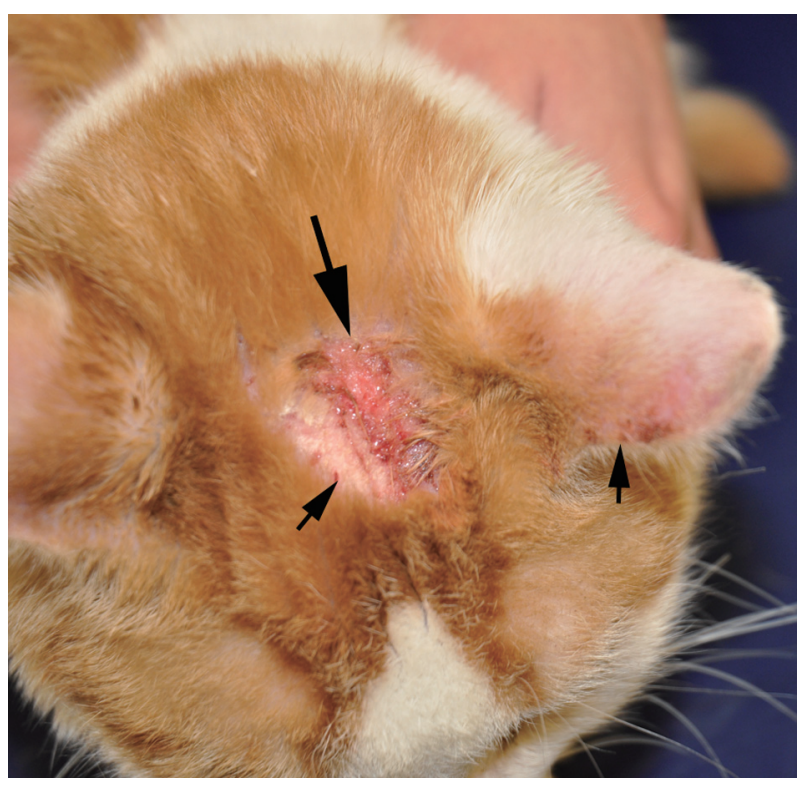

Fig. 1. Necrotizing vasculitis associated with cefovecin administration (case 28). Note the linear (large arrow) and punctate (small arrows) ulcers on the head and pinna.

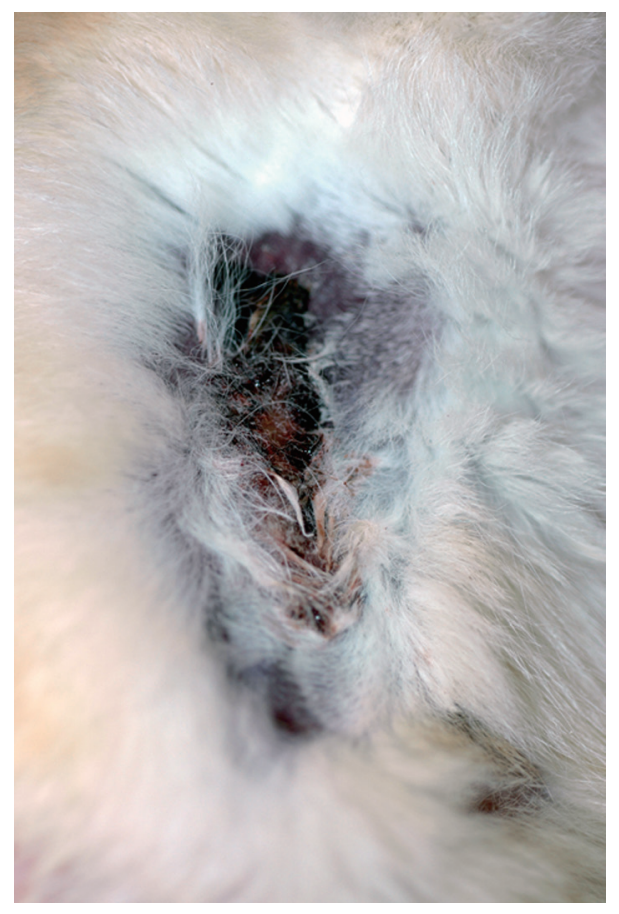

Fig. 3 Necrotizing vasculitis associated with cefovecin administration (case 29). Linear lesion with central ulcer and surrounding black necrotic tissue (eschar) on neck.

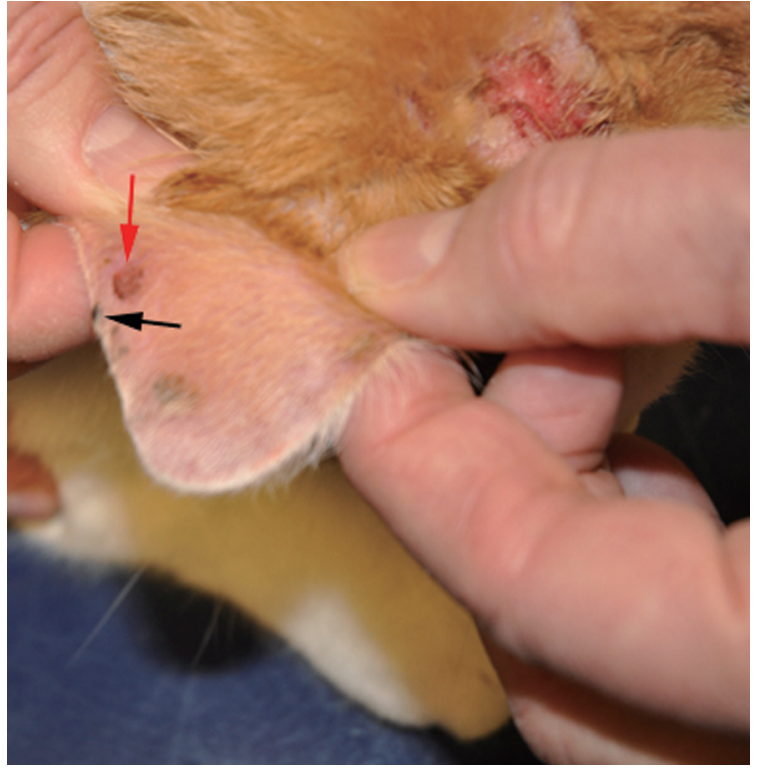

Fig. 2. Necrotizing vasculitis associated with cefovecin administration (case 28). Note punctate ulcers (green arrow) and black eschar (black arrow) on pinnal margin.

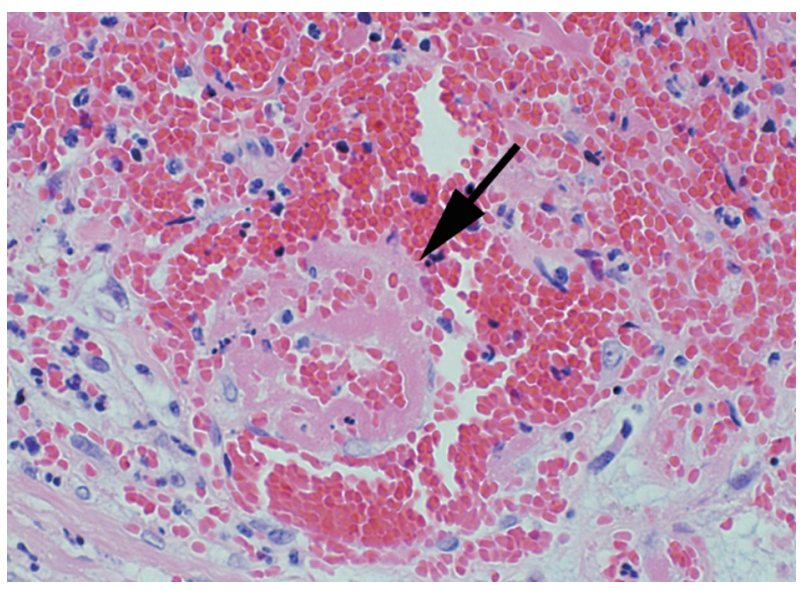

Fig. 4 Skin biopsy specimen from case 29. Central blood vessel (arrow) with fibrinoid necrosis of wall, intramural erythrocytes, and karyorrhectic nuclear debris (necrotizing vasculitis). There are also numerous perivascular extravasated erythrocytes. H\&E stain $400 \times$.

When the offending drug was stopped, the cutaneous eruption resolved over a period of 2 to 6 weeks in 25 of the cats. These cats received no anti-inflammatory treatment. However, in 4 cats (cases 6, 8, 28, 29), the lesions resolved more slowly over the course of 12 weeks. Two of the cats (cases 28 and 29) - which had necrotizing vasculitis (Figs. 1-4) - required treatment 
with dexamethasone and cyclosporine orally (case 29) or triamcinolone topically (case 28) before the lesions would heal.

The total duration of follow-up after the skin reactions had resolved ranged from 1 to 48 months. Rechallenge with presumed offending drugs was not performed in any of the cases.

\section{Discussion}

In general, no specific or characteristic laboratory findings indicate $\mathrm{ACDR}^{6,14)}$. Tests such as intradermal testing, patch testing, in vitro lymphocyte blastogenesis (transformation), and dermatopathologic analysis have been performed ${ }^{6,8,10,14)}$, but as the sensitivity and specificity of such tests are unknown, such tests are rarely used.

Since the diagnosis of ACDR is often based on the history, a variety of diagnostic algorithms and drug scoring systems have been proposed in humans ${ }^{1,2,8,10)}$, and have been modified and applied to $\operatorname{dogs}^{3,5,6)}$. However, the validity of these drug scoring systems in humans and dogs - and presumably cats - is questionable ${ }^{1,2)}$, and the systems cannot be relied upon in dogs and cats ${ }^{6,14)}$. The gold standard for the diagnosis of ACDR is rechallenge with the suspected offending drug ${ }^{6,11,14)}$. However, ethical considerations come into play, and re-exposure could produce a more severe reaction ${ }^{6,11,14)}$. Hence, we used standard criteria published elsewhere ${ }^{6,11,12)}$

ACDR accounted for $2 \%$ of the cats examined by the Dermatology Service, which is consistent with our previous report ${ }^{11)}$. In our study, we found no breed, age, or sex predilections. This is consistent with other reports ${ }^{6,11)}$. Although humans with human immunodeficiency virus (HIV) infection have an increased frequency of idiosyncratic ACDR, we and others $^{6,11)}$ found no association of idiosyncratic ACDR with retrovirus infection in cats.

Because ACDR can look like any known dermatologic lesions and affect any part of the integument, they can be included in the differential diagnosis of many cutaneous presentations $^{6,11,14)}$. The most common cutaneous reaction patterns in our study were contact dermatitis or contact otitis externa, and allergy-like symmetrical pruritus (particularly affecting the face and pinnae). These observations are consistent with previous reports $^{6,11)}$.
Many of the drugs incriminated in our study have been previously suspected ${ }^{6,11)}$. To our knowledge, we report for the first time presumed ACDR to 4 topical products (chlorhexidine scrub, fipronil spoton, imidacloprid spot-on, and selamectin spot-on). Topical products usually contain active ingredients (e.g., chlorhexidine, imidacloprid, fipronil) and several other ingredients that serve as surface active agents, vehicles, preservatives, and so forth (Table 2). Hence, it can be very difficult to identify the specific substance or combination of substances responsible for a contact reaction.

We also report for the first time ACDR to 7 systemic medications (cefadroxil, cefovecin, clindamycin, marbofloxacin, spirinolactone, sulfadimethoxineormetoprim, and timentin). The reactions to the cephalosporins, fluoroquinolone, sulfonamide, and synthetic penicillins are not surprising as ACDR to related compounds have been previously reported ${ }^{6,11,14)}$.

The treatment of ACDR includes drug withdrawal and supportive measures ${ }^{6,11,14)}$. This was successful in $93 \%$ (27/29 cats) of our patients. Two cats treated with cefovecin required additional anti-inflammatory therapy before control of the ACDR could be achieved. This is not surprising, as cefovecin is an extended-spectrum cephalosporin with measurable drug levels in blood and urine for at least 3 weeks post-injection ${ }^{12,13)}$ Idiosyncratic ACDR in cats and dogs often do not respond well to systemic glucocorticoid therapy until the offending drug is withdrawn ${ }^{6,11,14)}$.

In conclusion, we report 29 cases of presumed idiosyncratic ACDR. As ACDR can mimic virtually any naturally-occurring feline dermatosis, the clinician must always be aware of current drug history when evaluating a cat with skin disease.

\section{References}

1) Benahmed, S., Picot, M.C., Dumas, F. and Demoly, P. 2005. Accuracy of a pharmacovigilance algorithm in diagnosing drug hypersensitivity reactions. Arch. Intern. Med. 165: 1500-1505.

2) Benahmed, S., Picot, M.C., Hillaire-Buys, D., Blayac, J.P., Dujols, P. and Demoly, P. 2005. Comparison of pharmacovigilance algorithms in drug hypersensitivity reactions. Eur. J. Clin. Pharmacol. 61: 537-541.

3) Hinn, A., Olivry, T. and Luther, P. 1998. Erythema 
multiforme, Stevens-Johnson syndrome, and toxic epidermal necrolysis in the dog: clinical classification, drug exposure, and histopathologic correlations. J. Vet. Allergy Clin. Immunol. 6: 1320.

4) Lemo, N., Bernex, F., Hadjaje, C. and Marignac, G. 2008. Sterile neutrophilic dermatitis in a cat - a case report. Vet. Arch. 78: 261-267.

5) Mauldin, E.A., Palmeiro, B.S. and Goldschmidt, M.H. 2006. Comparison of clinical history and dermatologic findings in 29 dogs with severe eosinophilic dermatitis: a retrospective analysis. Vet. Dermatol. 17: 338-347.

6) Miller, W.H. Jr., Griffin, C.E. and Campbell, K.L. 2013. pp. 466-472. Muller \& Kirk's Small Animal Dermatology, $7^{\text {th }}$ ed. Elsevier, St. Louis.

7) Moore, G.E., DeSantis-Keer, A.C., Guptill, L.F., Glickman, N.W., Lewis, H.B. and Glickman, L.T. 2007. Adverse events after vaccine administration in cats: 2, 560 cases (2002-2005). J. Am. Vet. Med. Assoc. 231: 94-100.

8) Naranjo, C.A., Busto, U. and Sellers, E.M. 1981. A method for estimating the probability of adverse drug reactions. Clin. Pharmacol. Therap. 30: 239245.

9) Papadogiannakis, E.I. 2000. Cutaneous adverse drug reactions in the dog and cat. Eur. J. Comp.
Anim. Pract. 10: 71-77.

10) Perez, T., Dayer, E. and Girard, J.P. 1995. Hypersensitivity reactions to drugs: correlation between clinical probability score and laboratory diagnostic procedures. J. Invest. Allergy Clin. Immunol. 5: 275-282.

11) Scott, D.W. and Miller, W.H. Jr. 1998. Idiosyncratic cutaneous adverse drug reactions in the cat: literature review and report of 14 cases (19901996). Feline Pract. 26: 10-15.

12) Stegemann, M.R., Sherington, J., Coati, N., Brown, S.A. and Blanchflower, S. 2006. Pharmacokinetics of cefovecin in cats. J. Vet. Pharmacol. Therap. 29: 513-524.

13) Stegemann, M.R., Sherington, J. and Passmore, C. 2007. The efficacy and safety of cefovecin in the treatment of feline abscesses and infected wounds. $J$. Small Anim. Pract. 48: 683-689.

14) Voie, K.L., Campbell, K.L. and Lavergne, S.N. 2012. Drug hypersensitivity reactions targeting the skin in dogs and cats. J. Vet. Intern. Med. 26: 863-874.

15) Zoran, D.L., Boeck, L.A. and Booth, D.M. 2001. Hyperactivity and alopecia associated with ingestion of valproic acid in a cat. J. Am. Vet. Med. Assoc. 218: 1587-1589. 